\title{
Normokalsemik hiperparatiroidiye farklı bakış: Kardiyak sorunların gözden geçirilmesi
}

\section{A different view of normocalcemic hyperparathyroidism: The examination of cardiac problems}



'Hitit Üniversitesi, Çorum Eğitim ve Araştırma Hastanesi, Kardiyoloji Kliniği, Çorum/TÜRKiYE

${ }^{2}$ Yenimahalle Eğitim ve Araştırma Hastanesi İç Hastalıkları Kliniği, Ankara/TÜRKiYE

${ }^{3}$ Kırıkkale Üniversitesi Tıp Fakültesi, İç Hastalıkları ABD, Endokrinoloji ve Metabolizma Hastalıkları Bilim Dalı, Kırıkkale/TÜRKiYE

\section{öz}

Hiperparatiroidizmde renal komplikasyonlar ve osteoporoz gibi yan etkiler klinisyenler tarafından çok iyi bilinerek sıkı takip edilmektedir. Bununla birlikte yapılan çeşitli çalışmalarda hiperparatiroidiye bağlı hipertansiyon, diastolik disfonksiyon, endotel disfonksiyonu, kalp kapak kalsifikasyonu, aritmi, kardiyak hipertrofi gibi yan etkiler belirtilmiştir. Bazı çalışmalar hiperparatiroidide kardiak mortalite artışı olduğunu işaret etmektedir. Bu derlemede primer hiperparatiroidide rastlanan kardiyak sorunlara dikkat çekmek amaçlanmıştır.

Anahtar kelimeler: Hiperparatiroidi; kardiyak etkiler; hipertansiyon

\section{ABSTRACT}

While hyperparathyroidism is well known among the clinicians, such side effects as renal complications and osteoporosis are closely monitored. Besides various conducted studies have found out several side effects such as hypertension, diastolic dysfunction, endothelial dysfunction, heart valve calcification, arythmia, cardiac hypertropy. Even some studies have pointed to increase in cardiac mortality is correlated with hyperparathyroidizm. In this review, it is intended to raise a concern about cardiac complications occuring in primary hyperparathyroidism.

Keywords: Hyperparathyroidism; cardiac effects; hypertension

Sorumlu Yazar*: Şenay Durmaz, Kırıkkale Üniversitesi Tıp Fakültesi, İç Hastalıkları ABD, Endokrinoloji ve Metabolizma Hastalıkları Bilim Dalı, Kırıkkale/TÜRKIYE 


\section{Giriş}

Hiperparatiroidi yalnızca kemik metabolizmasını etkileyen bir endokrinolojik hastalık değildir. Primer hiperparatiroidili (PHPT) hastalar erken tanı nedeniyle asemptomatik ya da normokalsemik evrede yakalanmakta ve çoğu zaman paratiroidektomi geçirmeden yıllarca medikal tedaviyle ya da tedavisiz izlenmektedir [1]. Klinisyenlerin çoğu normokalsemik ya da asemptomatik primer hiperparatiroidi takibinde genellikle renal komplikasyonlara ya da osteoporoza odaklanmakta kardiyak sorunlar göz ardı edilmektedir [2]. Son yıllarda yapılan çalışmalar çelişkili olsa da hiperparatiroidinin kardiyak mortaliteyi artırdığı endişesi devam etmektedir. Kardiyak mortalite artışı beklenenin aksine hasta paratiroidektomigeçirse bile devam etmektedir [3].Yine primer hiperparatiroidide görülen hiperkalsemi ve hipofosfatemi de kardiyak sorunlara yol açabilmektedir [4]. Normokalsemik hiperparatiroidizmde ise bu iki elektrolit düzeyleri normal sınırlarda izlendiğinden kardiyak komplikasyonlardan hangi mekanizmaların sorumlu olduğu çok açık değildir.

Kardiyak sorunların başında ilk dikkat çeken hipertansiyon insidansındaki artış olmuştur $[2,5,6]$. Ancak daha sonraki veriler yaşa göre eşleştirildiğinde hiperparatiroidide hipertansiyon sıklığınınartmadığıyönündedir[1,7-9]. Primerhiperparatiroidili hastalarda ayrıca kalp kapaklarında kalsifikasyon, sol ventrikül hipertrofisi, miyokardial kalsifikasyon, koroner mikrovaskuler disfonksiyon nedeni ile kardiyovasküler hastalık riskinde artma [7], kalp yetmezliği, serebrovasküler hastalıklar, periferik arter hastalıkları, abdominal aort kalsifikasyonu, aritmi ve ani kardiyak ölümler görülebilmektedir [8,9]. Ayrıca primer hiperparatiroidili hastalarda dislipidemi, obezite, glukoz toleransında bozulma, hiperlipidemi, hipertansiyon gibi metabolik sendrom parametrelerinin artmış sıklığı kardiyak sorunlara eklenmektedir [10]. Normokalsemik ya da asemptomatik hiperparatiroidizmli hastalarda konu hala çok net değildir. Bu derlemede primer hiperparatiroidide rastlanan kardiyak sorunlara dikkat çekmek amaçlanmıştır.

\section{Paratiroid hormon ve sol ventrikül hipertrofisi}

Son günlerde yapılan çalışmalar düşük kemik kitlesi ile kardiyak mortalite arasında bir ilişki olduğunu ileri sürmekte ve bu konuda özellikle paratiroid hormon (PTH) ve vitamin D suçlanmaktadır [11,12]. PTH'in serumda artışı yaşlı erkeklerde kardiovaskuler mortalite için bir prediktördür [13]. PTH'ın aşırı artışının kalp ve arter duvarını etkilediği hem yapısal hem de fonksiyonel bozukluklarla ilişkili olduğu anlaşıldıktan sonra bu konuda yapılan çalışmalar sıklaşmıştır
[8,13,14]. Soares ve arkadaşları [15] 80 yaş üzerindeki yaşlı ama sağlıklı kişilerde yaptıkları çalışmalarında PTH artışının konsantrik sol ventrikül hipertrofisi ile ilişkili bulurken, arteriel duvarın yapı ve fonksiyonu, karotid arter elastisitesi ile bir ilişki saptamadılar. Walker ve ark [16] yaptığı bir başka çalışmada hafif hiperparatiroidili hastalarda subklinik karotid arter anormallikleri, aortik kapak kalsifikasyonlarında artış saptanırken sol ventrikul kitle indeksi ve kardiyak fonksiyonlar normal bulundu.

Hiperkalsemi kardiak hipertrofiye sebep olabilir [8]. Ancak hiperkalsemi olmasa da PTH'ın kendisinin kardiyak miyositlerde ve damar düz kaslarında hipertrofiye yol açtığı artık bilinmektedir $[8,15,16]$. Gençlerde yapılmış çalışmalarda da PTH artışı ile orantılı olarak sol ventrikül hipertrofisi gösterilmiştir [17]. Hatta PTH normalin üst sınırında olsa bile özellikle yaşı ı erkeklerde kardiyak mortalite artışına neden olduğu gösterilmiştir [18]. Mekanizması tam olarak anlaşılamasa da PTH kardiyak miyositlere direkt hipertrofik bir etki gösteriyor olabilir. İntraselluler kalsiyum artışı yüzünden protein kinaz $C$ yolağının aktive olması ile MEK/ERK/1/2 aktivasyonu gerçekleşmekte ve hücresel proteinlerde hem de kardiyak ventrikül kitlesindeki artış ile sonuçlanabilmektedir [8,19-21]. Buradaki sorun PTH artışının ne kadar sürede ve hangi şiddette bu tür yeniden düzenlenmeyi tetikleyeceğinin çok açık olmamasıdır. Soares ve arkadaşları [15] PTH düzeyleri yüksek olan kişilerde $\mathrm{E}$ dalga deselerasyon zamanında kısalma olduğunu, sol ventrikül stiffnesinin ve sol atrial afterloadunun artarak sol atriumda genişlemeye neden olduğunu gösterdiler. PTH aynı zamanda inotropik etkilerle kalp hızını ve koroner kan akımını artırıyor olabilir [22]. Diğer bir mekanizma ise arteriel stifness artışının PTH tarafından induklenerek kardiyak afterloadu artırarak LVH yaratmasıdır [23].

McMahon ve arkadaşlarının [24] yaptığı 15 çalışmanın metaanalizinde primer hiperparatiroidili hastalarda paratiroidektominin sol ventrikül myokard indeksinde 11.6 $\mathrm{g} / \mathrm{m} 2$ azalmaya yol açtığı gösterilmiştir. Preoperatif PTH düzeyindeki artış şiddeti ile LV kitlesi arasında ilişki varken kalsiyum düzeyleri ile orantılı bir ilişki görülmemiştir [24]. Hiperkalsemili kişilerde kardiyak relaksasyonun bozulduğu eskiden beri bilinmektedir [25]. Ancak bu metaanalizde kalsiyum yüksekliğinden ziyade PTH yüksekliğinin LVH'ne yol açan bir faktör olabileceği ileri sürülmüştür [24]. Bazı çalışmalarda ise paratiroidektomi sonrasında LV kitlesinde herhangi bir azalma gösterilememiş olması kısa gözlem süreli çalışmalarda bias olduğunu düşündürmüştür [24]. 
Primer hiperparatiroidili hastalarda yapılan ekokardiografik değerlendirmelere göre sistolik fonksiyonlar genellikle normal bulunurken E/A oranları ve izovolumetrik relaksasyon zamanında uzama gibi diastolik disfonksiyonu gösteren parametrelerde bozulma olduğu bildirilmişse de normal olduğunu gösteren çalışmalar konuyu daha tartışmalı hale getirmiştir [8,24]. Özdemir D ve arkadaşlarının [8] yaptığı bir çalışmada çok ilginç olarak M-mod ve pulsed-wave Doppler ekokardiyografik bulgular normal bulunmuş ancak primer hiperparatiroidili hasta gruplarında daha ileri bir yöntem olan tissue doppler imaging ve strain rate ekokardiyografisi ile değerlendirme yapıldığında hem sistolik hem de diastolik fonksiyon kusurları oluştuğu ve subklinik yapısal bozuklukların geliştiği raporlandı. Büyük olasılıkla kalsiyum yüküne sekonder intraselluler Ca artışı kalpte relaksasyonu azaltarak diastolik disfonksiyona sebep oluyor gibi görünmektedir [27]. Yine Özdemir ve arkadaşları [8] aynı çalışmada tissue doppler ekokardiyografi kullanarak miyokardial performans indeksini primer hiperparatiroidili hastalarında yüksek ölçtüler.

Diğer yandan Sin ve arkadaşları [28] Kore'li son dönem böbrek yetmezliği olan sekonder hiperparatiroidili hastalarda kalsiyum sensör reseptörüne etki eden cinecalcet'in kalsiyum, fosfor ve PTH düzeylerini normale getirmekle birlikte kardiyovaskuler mortaliteyi azaltmadığını gösterdi. Ancak daha önce yapılmış bazı çalışmalarda kronik böbrek yetersizliğine bağlı sekonder hiperparatiroidide paratiroidektomi sonrası kardiyak fonksiyonların düzeldiği gösterilmiştir [29]. Nanosato ve ark. [30] son dönem böbrek yetersizliği olan sekonder hiperparatiroidili bir kadında lokal minimal invaziv paratiroidektomi sonrası kardiyak performansı New York Heart Association'a göre klas 3'den klas 1'e gerilediğini ve ekokardiyografik parametrelerin düzeldiğini gözlemlediler. Ancak kronik böbrek yetmezliğinin son evresindeki sekonder hiperparatiroidili hastalarda hipertansiyon, volüm ve basınç yükünün artması ve organik miyokardial hasar sol ventrikül disfonksiyonunda sorumlu diğer faktörler olduğundan (30) primer hiperparatiroididen biraz daha kompleks kardiyak sorunlar doğurması kaçınılmazdır. Kronik olarak yüksek PTH'a maruz kalma mitokondriumda carnitine palmitoil transferase 1 aktivitesini azaltarak yağ asitlerinin beta oksidasyonunu bozmakta ve miyokard fonksiyonlarını azaltmaktadır [30,31].

\section{Hiperparatiroidi kan basıncını artırır mı?}

Hem primer hem de sekonder hiperparatiroidide hipertansiyon sıklığında bir artış olduğu görüşü çelişkilidir [32]. Özellikle normokalsemik hiperparatiroidi gibi hastalığın daha subklinik seyrettiği durumlarda hipertansiyonun düşük fosfor düzeyleri ile de ilişkili olabileceği ileri sürülmektedir [33].

Diğer ilginç ve beklenmeyen bir mekanizma primer hiperparatiroidili hastalarda Brunauld ve ark. tarafından $[8,21]$ gözlenen aldosteron artışıdır. Hiperaldosteronizm de kan basıncı artışına katkı sağlıyor olabilir. Paratiroidektomiden sonra hem aldosteron düzeyleri hem de kan basıncı azalmaktadır. PTH baroreseptörlerden bağımsız olarak direkt zona glomerulozaya etki ederek PTH/PTHRP reseptörlerine bağlanmakta sitozolik kalsiyum artışına neden olmakta ve ayrıca renin salınımını direkt artırarak hiperaldosteronizme ve hipertansiyona sebep olmaktadır [2,34-36]. Aynı zamanda diğer vazopresörlere sensitivite artmaktadır [2]. Yine primer hiperparatiroidili hastalarda atheroskleroz ile yakın ilişkisi olduğu bilinen karotis intima media kalınlığı ve plak kalınlıklarındaki artış ile karotis stifnessi artmaktadır [16]. Paratiroidektomiden sonra bu bulgularda gerileme olur [16]. Ancak çalışmaların bir çoğu bu konuda çelişkili sonuçlanmıştır. İlginç olarak PTH infüzyonu hipertansif hastalarda kan basıncını düşürürken, normotansif hastalarda kan basıncını artırmaktadır. PTH damar düz kas hücrelerinde ca influxunu ve hücre içi cAMP artışını sağlayarak vazodilatasyona yol açtığı, uzun süreli PTH uyarısının ise reseptörerde desensitizasyon yarattığı sanılmaktadır. Kan basınçları yanıtları kişiden kişiye ve hiperparatiroidi süresine göre değişken olabilir [2,37,38].

\section{Hiperparatiroidi ve aritmi}

Primer hiperparatiroidide gelişen hiperkalsemi klasik bilgi olarak QT intervalinde kısalmaya, ST segmentinde azalmaya, PR ve QRS intervallerinde ise hafif uzamaya sebep olmaktadır [39]. T dalgası düzleşebilir ya da tersine döner, çeşitli derecelerde kalp blokları gelişebilir [40]. QT kısalması nedeniyle refraktör periyotun kısalması kompleks ventriküler aritmilere ya da ani ölümlere yol açabilmektedir [39]. Hafif düzeyde hiperkalsemi ile seyreden primer hiperparatiroidili hastalarda paratiroidektomiden sonra kardiyak ventriküler depolarizasyonda kısalma olmasına rağmen, EKG değişiklikleri hiperkalseminin derecesi önceden belirlenemez. Primer hiperparatiroidili ve hafif hiperkalsemili hastalarda kardiyak aritmiler oldukça nadir görülmektedir. Rosenqvist ve arkadaşları [39] orta düzeyde hiperkalsemisi olan primer hiperkalsemili kişilerde repolarizasyon fazı kısalsa bile klinik olarak belirgin bir kardiyak iletim defekti görülmediğini 20 vaka üzerinde gösterdiler. Dokupiliva A ve ark. [40] PHPT'li hastalarda 24 saatlik EKG monitorizasyonunun QT kısalsa bile aritmilerin tespitinde ek yarar getirmediğini gösterdiler. 


\section{Hiperparatiroidi ve oksidatif stres}

Primer hiperparatiroidili hastalarda endotel fonksiyonlarında bozulma olduğu eskiden beri bilinmektedir. Reaktif oksijen ürünlerinde artma ve endojen antioksidan kapasitede azalma kalsiyum yükü ile ilişkilendirilmiştir. Bazı çalışmalarda kalsiyumdan çok yüksek PTH düzeyleri ile endotel disfonksiyonu arasında direkt ilişki bildirilmiştir [8,41,42].

\section{Serum vitamin D düzeyleri ve kardiyak bozukluklar}

Genellikle PTH yüksekliği serum 25-OH Vitamin D düzeyleri ile negatif korelasyon gösterir [43]. Vitamin D endotelde reseptörlerine bağlanarak düz kas hücre proliferasyonunu ve migrasyonunu inhibe etmektedir $[8,44,45]$. Bu durum primer hiperparatiroidili olgularda artmış atheroskleroz riskini biraz da olsa açıklayabilir. Vitamin D eksikli ile renin ve aldosteronda artma, glukoz intoleransı, proinflamatuar sitokinlerin artması gibi diğer katkı sağlayan mekanizmalar da rol oynayabilir [44]. Vitamin D eksikliği kalp yetmezliği olan kişilerin klinik durumunun kötüleşmesine sebep olan diğer bir faktör olarak ileri sürülmektedir [43]. Yaşlı hastalarda vitamin D eksikliği ve beraberinde gelişen sekonder hiperparatiroidi kalp yetmezliğinin şiddetlenmesine ve uzun dönem survive'ın bozulmasına hastane yatışlarının artmasına ve NT-proBNP artışına sebep olamaktadır [46]. Invitro çalışmalar fizyolojik dozda uygulanan aktif vitamin D'nin vaskuler düz kas sitostazını sağlayarak ve makrofaj scavanger reseptörlerinin expresyonunu kısıtlayarak atherosklerozisi kontrol ettiğini düşündürmektedir [43,47]. Ayrıca Vitamin D reseptör knockout edilmiş farelerde renin anjiotensin sistemi aktive olmakta kardiyak kitlede ve miyokard kalınlığında artışa sebep olmaktadır [43]. Bu nedenle PHPT'li hastalarda hiperkalsemiyi tetikleyeceği endişesi ile vitamin D vermekten kaçınmak kalp yetmezliğı olan hastalarda kardiyak sorunları artırabilir.

\section{Paratiroidektomi sonrası kardiyak disfonksiyon düzelir mi?}

Primer hiperparatiroidili hastaların çoğu asemptomatik dönemde tesadüfen saptanmakta ve şu anda kabul gören 4. Workshop kriterlerine göre [48] operasyon endikasyonu olmayan hastalar yıllarca takip edilmektedir. Hali hazırdaki kılavuz kardiyak disfonksiyonu operasyon endikasyonu olarak değerlendirmemektedir. Yıllarca takip edilen hastalarda kardiyaksorunlarınilerleyipilerlemeyeceğidebilinmemektedir. Walker TR ve ark [16] yaptığı bir çalışmada Ca seviyesi 12 $\mathrm{mg} / \mathrm{dL}$ 'nin altındaki hafif PHP'li hastalarda subklinik karotis vaskuler anormallikleri, artmış aortik kapak kalsifikasyonlarını gösterdiler. Karotis intima/ media kalınlığı oranı ve plak kalınlığı ile karotis stiffnessi de artmıştır [16]. Paratiroidektomi sonrası 2 yıl takip ettikleri hastalarında paratiroidektominin bazı kardiyak bulguları düzelttiğini bazılarının ise değişmeden sebat ettiğini gösterdiler. Paratiroidektomiden sonra özellikle karotis stifnesinde belirgin azalma olduğunu bildirdiler [16]. Bazı çalışmalar paratiroidektomi sonrası sol ventrikül kitlesinde azalma bildirse de Walker ve ark [16] yaptıkları çalışmada kardiyak indekslerde düzelme olmadığını gözlemlediler. Diastolik disfonksiyonda da genellikle düzelme olmamaktadır [16]. Hafif hiperparatiroidili hastalarda diyastolik fonksiyonlar ve sol ventrikül kitlesinde genellikle artış görülmemektedir. Aortik valv kalsifikasyonları da paratiroidektomi sonrası irreversibl olan bir bulgudur.

Sonuç olarak; asemptomatik hiperparatiroidili ve normokalsemik hiperparatiroidili hastaların yıllar süren uzun süreli klinik takiplerinde kardiyak bozuklukların da dikkatle izlenmesi gerekmektedir. Kılavuzlarda henüz yeterince yer almasa da veriler PHPT'li hastalarda kardiyak açıdan yeni bir bakış açısının olması gerektiğini işaret etmektedir. Fizyopatolojilerin daha net anlaşılabilmesi bu konuda ileri çalışmaların yapılması ile gerçekleşecektir.

\section{Maddi Destek ve Çıkar İlişkisi}

Çalışmayı maddi olarak destekleyen kişi/kuruluş yoktur ve yazarların çıkara dayalı bir ilişkisi yoktur.

\section{Kaynaklar}

1. Andersson P, Rydberg E, Willenheimer R. Primary hyperparathyroidism and heart disease--a review. Eur Heart J 2004; 25: 1776-87.

2. Kalla A, Krishnamoorthy P, Gopalakrishnan A, Garg J, Patel NC, Figueredo VM. Primary hyperparathyroidism predicts hypertension: Results from the National Inpatient Sample. Int J Cardiol 2017; 227: 335-37

3. Heath III, Hunter, Stephen F. Hodgson, Margaret A. Kennedy. "Primary hyperparathyroidism: incidence, morbidity, and potential economic impact in a community." Nejm 1980; 302: 189-93.

4. Amanzadeh J, Reilly RF Jr. Hypophosphatemia: an evidencebased approach to its clinical consequences and management. Nat Clin Pract Nephrol 2006; 2: 136-48.

5. Fardella C, Rodriguez-Portales JA. Intracellular calcium and blood pressure: comparison between primary hyperparathyroidism and essential hypertension. J Endocrinol Invest 1995; 18: 827-32.

6. Gennari C, Nami R, Gonnelli S. Hypertension and primary hyperparathyroidism: the role of adrenergic and renin-angiotensinaldosterone systems. Miner Electrolyte Metab 1995; 21: 77-81. 
7. Osto E, Fallo F, Pelizzo MR et al. Coronary microvascular dysfunction induced by primary hyperparathyroidism is restored after parathyroidectomy. Circulation 2012; 126: 1031-39.

8. Ozdemir D, Kalkan GY, Bayram NA et al. Evaluation of left ventricle functions by tissue Doppler, strain, and strain rate echocardiography in patients with primary hyperparathyroidism. Endocrine 2014; 47: 609-17.

9. J.L. Anderson, R.C. Vanwoerkom, B.D. Horne, T.L. Bair, H.T. May, D.L. Lappé, J.B. Muhlestein, Parathyroid hormone, vitamin D, renal dysfunction, and cardiovascular disease: dependent or independent risk factors? Am. Heart J 2011; 162: 331-39.

10. D. Han, S. Trooskin, X. Wang, Prevalence of cardiovascular risk factors in male and female patients with primary hyperparathyroidism. J. Endocrinol. Invest 2012; 35: 548-52.

11. Stefenelli T, Abela C, Frank $\mathrm{H}$ et al. Cardiac abnormalities in patients with primary hyperparathyroidism: implications for follow-up. J Clin Endocrinol Metab 1997; 82: 106-12.

12. Palmer $M$, Adami HO, Bergström R, Jakobsson S, Akerström G, Ljunghall S. Survival and renal function in untreated hypercalcaemia. Population-based cohort study with 14 years of follow-up. Lancet 1987; 1: 59-62.

13. Hagstrom M, Hellman EP, Larsson TE et al. Plasma parathyroid hormone and the risk of cardiovascular mortality in the community. Circulation 2009; 119: 2765-71.

14. Buizert PJ, van Schoor NM, Simsek S et al. PTH: a new target in arteriosclerosis? J Clin Endocrinol Metab 2013; 98: 1583-90.

15. Soares AA et al. "Enhanced parathyroid hormone levels are associated with left ventricle hypertrophy in very elderly men and women." J Am Society Hypertens 2015; 9: 697-704.

16. Walker MD, RundekT, Homma S et al. Effect of parathyroidectomy onsubclinical cardiovascular disease in mild primary hyperparathyroidism. Eur J Endocrinol 2012; 167: 277-85.

17. Johnstone LM, Jones CL, Grigg LE, Wilkinson JL, Walker RG, Powell HR. Left ventricular abnormalities in children, adolescents and young adults with renal disease. Kidney Int 1996; 50: 998-1006.

18. Taylor EN, Curhan GC, Forman JP. Parathyroid hormone and the risk of incident hypertension. J Hypertens 2008; 26: 1390-94.

19. Schlüter KD, Weber M, Piper HM. Parathyroid hormone induces protein kinase $C$ but not adenylate cyclase in adult cardiomyocytes and regulates cyclic AMP levels via protein kinase C-dependent phosphodiesterase activity. Biochem J 1995; 310: 439-44.
20. X. Liu, R. Xie, S. Liu, Rat parathyroid hormone 1-34 signals through the MEK/ERK pathway to induce cardiac hypertrophy. J Int Med Res 2008; 36: 942-50.

21. L. Brunaud, A. Germain, R. Zarnegar et al. Serum aldosterone is correlated positively to parathyroid hormone (PTH) levels in patients with primary hyperparathyroidism. Surgery 2009; 146: 1035-41.

22. Ogino K, Burkhoff D, Bilezikian JP. The hemodynamic basis for the cardiac effects of parathyroid hormone (PTH) and PTHrelated protein. Endocrinology 1995; 136: 3024-30.

23. Pirro M, Manfredelli MR, Helou RS et al. Association of parathyroid hormone and 25-OH-vitamin D levels with arterial stiffness in postmenopausal women with vitamin D insufficiency. J Atheroscler Thromb 2012; 19: 924-31.

24. McMahon DJ, Carrelli A, Palmeri $\mathrm{N}$ et al. Parathyroidectomy upon left ventricular mass in primary hyperparathyroidism: $A$ meta-analysis. J Clin Endocrinol Metab 2015; 100: 4399-407.

25. Nappi S, Saha $H$, Virtanen $V$ et al. Left ventricular structure and function in primary hyperparathyroidism before and after parathyroidectomy. Cardiology 2000; 93: 229-33.

26. Barletta G, De Feo ML, Del Bene R et al. Cardiovascular effects of parathyroid hormone: a study in healthy subjects and normotensive patients with mild primary hyperparathyroidism. J Clin Endocrinol Metab 2000; 85: 1815-21.

27. S.A. Camacho, R. Brandes, V.M. Figueredo, M.V. Weiner, Ca2 + transient decline and myocardial relaxation are slowed during low flow ischemia in rat hearts. J Clin Invest 1994; 93: 951-57.

28. Sin HY. Prospective cohort study: Cinacalcet-mediated lowering of PTH level and cardiovascular disease mortality in younger Korean patients with stage 5 CKD at a Korean secondary hospital. J Clin Pharm Ther 2017; 5: 607-14

29. Nagashima $M$, Hashimoto $K$, Shinsato $T$ et al. Marked improvement of left ventricularfunction after parathyroidectomy in a hemodialysis patient with secondary hyperparathyroidism and left ventricular dysfunction. Circ J 2003; 67: 269-72.

30. Nanasato $\mathrm{M}$, Goto $\mathrm{N}$, Isobe $\mathrm{S}$ et al. Restored cardiac conditions and left ventricular function after parathyroidectomy in a hemodialysis patient. Parathyroidectomy improves cardiac fatty acid metabolism assessed by 123I-BMIPP. Circ J 2009; 73: 1956-60.

31. Smogorzewski M, Perna AF, Borum PR, Massry SG. Fatty acid oxidation in the myocardium: Effects of parathyroid hormone and CRF. Kidney Int 1988; 34: 797-803.

32. Schiffl H, Lang SM. Hypertension Secondary to PHPT: Cause or Coincidence? Int J Endocrinol 2011; 2011: 974647. 
33. Kizilgul M, Beketaev I, Dolapoglu A. Letter to the Editor: Could Low Phosphate Level Be the Reason for High Risk of Hypertension in Normocalcemic Primary Hyperparathyroidism? J Clin Endocrinol Metab 2015; 100: 39.

34. Tomaschitz A, Ritz E, Pieske B et al. Aldosterone and parathyroid hormone: a precarious couple for cardiovascular disease. Cardiovasc Res 2012; 94: 10-19.

35. Zia AA, Kamalov G, Newman KP et al. From aldosteronism to oxidative stress: the role of excessive intracellular calcium accumulation. Hypertens Res 2010; 33: 1091-101.

36. Bernini G, Moretti A, Lonzi S, Bendinelli C, Miccoli P, Salvetti A. Renin-angiotensin-aldosterone system in primary hyperparathyroidism before and after surgery. Metabolism 1999; 48: 298-300.

37. D. Fliser, E. Franek, P. Fode et al. Subacute infusion of physiological doses of parathyroid hormone raises blood pressure in humans. Nephrol Dial Transplant 1997; 12: 933-38.

38. B. Jespersen, A. Randlov, J. Abrahamsen et al.The altered pattern of reactivity may counteract raised blood pressure Am J Hypertens 1997; 10: 1356-67.

39. Rosenqvist M, Nordenström J, Andersson M, Edhag OK. Cardiac conduction in patients with hypercalcaemia due to primary hyperparathyroidism. Clin Endocrinol (Oxf) 1992; 37: 29-33.

40. Dokupilova A, Payer J. 24-hour outpatient ECG as a screening method in patients with primary hyperparathyroidism. Bratis Lek Listy 2016; 117: 495-500.

41. C. Bosworth, M.C.Sachs, D. Duprez et al. Parathyroid hormone and arterial dysfunction in the multi-ethnic study of atherosclerosis. Clin. Endocrinol (Oxf) 2013; 79: 429-36.
42. Ekmekci A, Abaci N, Colak ON et al. Endothelial function and endothelial nitric oxide synthase intron $4 \mathrm{a} / \mathrm{b}$ polymorphism in primary hyperparathyroidism. J Endocrinol Invest 2009; 32: 611-16.

43. Izumi G, Inai K, Shimada E, Nakanishi T. Vitamin D Kinetics and Parathyroid Gland Function in Patients with Congenital Heart Disease. Congenit Heart Dis 2016; 11: 700-706.

44. Y.C. Ku, M.E. Liu, C.S. Ku, T.Y. Liu, S.L. Lin, Relationship between vitamin D deficiency and cardiovascular disease. World J Cardiol 2013; 5: 337-46.

45. Wang L, Song $Y$, Manson JE et al. Circulating 25-hydroxy-vitamin D and risk of cardiovascular disease: a meta-analysis of prospective studies. Circ Cardiovasc Qual Outcomes 2012; 5: 819-29.

46. Loncar G, Bozic B, Cvetinovic N et al. Secondary hyperparathyroidism prevalence and prognostic role in elderly males with heart failure. J Endocrinol Invest 2017; 40: 297-304.

47. Suematsu $Y$ et al. Effect of 1,25-dihydroxyvitamin D3 on induction of scavenger receptor and differentiation of 12-O-tetradecanoylphorbol-13-acetate-treated THP-1 human monocyte like cells.Journal of cellular physiology 1995; 165: 547-55.

48. Wilhelm SM, Wang TS, Ruan DT et al. The american association of endocrine surgeons guidelines for definitive management of primary hyperparathyroidism. JAMA Surg 2016; 151: 959-68. 